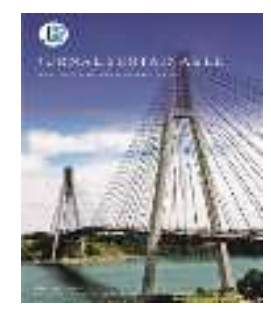

\title{
Perancangan Sistem Kontrol dan Monitoring Kualitas Air dan Suhu Air Pada Kolam Budidaya Ikan
}

\author{
Rozeff Pramana \\ Jurusan Teknik Elektro, Fakultas Teknik, Universitas Maritim Raja Ali Haji \\ Jl. Politeknik Senggarang, Tanjungpinang 29100 \\ rozeff@umrah.ac.id
}

\begin{abstract}
The quality and the temperature of pond water is an important parameter that need to get attention in fish cultivation. Every type of fish has their own characteristic towards water condition and pond temperature. The monitoring of water quality in cultivation pond is done manually and it takes a lot of time. The purpose of this research is to design web-based control system device and monitoring the quality of the water of fish cultivation pond including salinity, temperature and the hardness in real time using special application. This device design consists of salinity sensor, hardness sensor, and temperature sensor. Temperature can be controlled and monitored automatically on the application via computer/laptop. The result of this research is temperature drop by $0,1{ }^{\circ} \mathrm{C}$ on a 10 liters pond that takes 18 seconds, and to decrease the temperature of $1{ }^{\circ} \mathrm{C}$ takes 180 seconds ( 3 minutes). To raise the temperature of $0,1{ }^{\circ} \mathrm{C}$ takes 264 seconds or 4,4 minutes, and to raise the temperature of $1{ }^{\circ} \mathrm{C}$ takes 2640 seconds or 44 minutes. The percentage of error for sensor reading is ranged $2,4 \%-3,9 \%$.
\end{abstract}

Keywords - water quality, cultivation, automatic control, monitoring, sensor, Arduino, web.

Intisari- Kualitas dan suhu air kolam merupakan parameter penting yang perlu mendapat perhatian dalam budidaya ikan. Setiap jenis ikan memiliki karakteristik berbeda terhadap kondisi air dan temperatur kolam. Pemantauan kualitas air pada kolam budidaya banyak dilakukan secara manual dan memerlukan waktu yang lama. Tujuan penelitian ini merancang perangkat sistem kontrol dan monitoring kualitas air pada kolam budidaya ikan berbasis Web yang meliputi salinitas, suhu dan kesadahan secara real time menggunakan aplikasi khusus. Perangkat rancangan ini terdiri dari sensor salinitas, sensor kesadahan dan sensor suhu. Suhu dapat dikontrol dan dimonitoring secara otomatis pada applikasi melalui komputer/laptop. Hasil penelitian ini penurunan suhu sebesar $0,1^{\circ} \mathrm{C}$ pada kolam berkapasitas 10 liter membutuhkan waktu 18 detik, dan untuk menurunkan suhu sebesar $1^{\circ} \mathrm{C}$ membutuhkan waktu 180 detik ( 3 menit). Untuk menaikan suhu $0,1^{\circ} \mathrm{C}$ dibutuhkan waktu 264 detik atau 4,4 menit, dan untuk menaikan suhu sebesar $1{ }^{\circ} \mathrm{C}$ dibutuhkan waktu 2640 detik atau 44 menit. Persentase error dari pembacaan sensor berkisar 2,4\% - 3,9\%.

Kata kunci - kualitas air, budidaya, kontrol otomatis, monitoring, sensor, Arduino, web.

\section{Pendahuluan}

Indonesia adalah negara maritim yang terdiri dari beribu pulau dengan luas terbentang sepanjang 3977 mil antara samudra Hindia dan samudara Pasifik, dari luas tersebut $75 \%$ adalah lautan dan 25\% daratan [1]. Dengan kondisi geografis tersebut, sektor perikanan menjadi salah satu sektor potensial guna menunjang perekonomian Indonesia. Permintaan yang cukup tinggi oleh negara-negara tetangga seperti Malaysia, Singapura, Jepang dan China untuk 
berbagai jenis ikan konsumsi selayaknya menjadi peluang besar bagi nelayan Indonesia dan industri perikanan untuk memenuhi permintaan pasar tersebut.

Departemen Populasi Divisi Urusan Sosial dan Ekonomi PBB memperkirakan bahwa populasi penduduk dunia saat ini mencapai hampir 7,6 miliar. Laju pertumbuhan penduduk tersebut menuntut peningkatan konsumsi ikan.

Peluang pengembangan usaha perikanan Indonesia memiliki prospek yang sangat tinggi. Potensi ekonomi sumber daya kelautan dan perikanan yang dapat dimanfaatkan untuk mendorong pertumbuhan ekonomi diperkirakan mencapai USD 82 miliar per tahun. Potensi sumber daya ikan laut Indonesia sebesar 6,5 juta ton per tahun tersebar di berbagai perairan wilayah Indonesia dan perairan Zona Ekonomi Eksklusif Indonesia (ZEEI) yang terbagi dalam sembilan wilayah perairan utama Indonesia. Volume dan nilai produksi untuk setiap komoditas unggulan perikanan budidaya dari tahun 2010-2014 mengalami kenaikan, terdiri dari: (1) Udang mengalami kenaikan rata-rata per tahun sebesar 14,03\%; (2) Kerapu mengalami kenaikan rata-rata per tahun sebesar 9,61\%; (3) Bandeng mengalami kenaikan ratarata per tahun sebesar $10,45 \%$; (4) Patin mengalami kenaikan rata-rata per tahun sebesar 30,73\%; (5) Nila mengalami kenaikan rata-rata per tahun sebesar 19,03\%; (6) Ikan Mas mengalami kenaikan rata-rata per tahun sebesar 14,44\%; (7) Lele mengalami kenaikan rata-rata per tahun sebesar 26,43\%; (8) Gurame mengalami kenaikan rata-rata per tahun sebesar 17,70\%; dan (9) Rumput Laut mengalami kenaikan rata-rata per tahun sebesar $27,72 \%$. (David Setia Maradong, 2016) [2].

Pembudidayaan ikan berorientasi pada kelestarian lingkungan merupakan hal yang perlu mendapat perhatian. Ikan akan hidup dan berkembang biak dengan baik bila syarat-syarat lingkungan yang disediakan sesuai dengan kondisi hidupnya bisa terpenuhi atau mendekati habitat aslinya. Kualitas air merupakan salah satu parameter utama dalam budidaya ikan.
Kualitas air dapat dilihat dari besaran kimia maupun besaran fisik. Besaran kimia tersebut meliputi kadar $\mathrm{pH}$, salinitas, kesadahan dan kandungan senyawa kimia. Sifat-sifat kimia air berhubungan dengan pembawa zat-zat hara yang diperlukan bagi pembentukan bahan-bahan organik bagi tumbuhan. Karakteristik fisik meliputi bahan padat keseluruhan yang terapung maupun yang terlarut, kekeruhan, warna, bau, rasa, dan temperatur (suhu) air. Sifat-sifat fisik air berhubungan dengan medium tempat hidup tumbuh-tumbuhan dan hewan [3]. Pemantauan kualitas air pada kolam budidaya ikan saat ini masih banyak dilakukan dengan cara manual dengan langsung mengukur kualitas air ke kolam budidaya, hal ini tentunya tidak efektif dan memerlukan waktu yang lama serta tidak effisien.

Temperatur pada air kolam budidaya juga berpengaruh terhadap organisme yang ada dalam kolam tersebut. Diantaranya mempengaruhi tingkat viskositas air, distribusi mineral dalam air, konsentrasi oksigen terlarut, dan kadar oksigen. (Armanto, dkk. 2013) [4]. Peningkatan dan penurunan suhu air kolam budidaya yang tidak sesuai dengan kondisi ikan akan menyebabkan ikan mengalami kesulitan melakukan proses mobilisasi energi dan mengakibatkan kematian dalam waktu singkat.

Pentingnya pemantauan secara kontinyu kualitas air dan suhu air pada keberhasilan budidaya perikanan, maka perlu dirancang suatu perangkat sistem kontrol dan monitoring kualitas air dan suhu air pada kolam budidaya ikan, yang dapat dikontrol secara otomatis dan dimonitoring dari jauh. Parameter kualitas air yang dikontrol pada penelitian ini terdiri atas salinitas, kadar zat kapur (kesadahan) dan suhu.

\section{KAJIAN LITERATUR}

Kajian terdahulu terkait judul penelitian ini sebelumnya pernah dilakukan oleh Mahfudz, S. dan Rahardjo, P.M., (2008) [5], dengan judul pengukur Suhu dan $\mathrm{pH}$ Tambak Air Terintegrasi dengan Data Logger. Penelitian tersebut merancang perangkat pengukur tingkat keasaman $(\mathrm{pH})$ dan suhu air pada tambak. 
Perangkat ditempatkan dilapangan untuk pengawasan secara terus menerus.

Penelitian selanjutnya [6], dengan judul Water Quality Monitoring System Using Wireless Sensor Network. Tujuan penelitian tersebut adalah memonitoring lingkungan dalam hal pengawasan kualitas air dengan berbagai parameternya seperti suhu, derajat keasaman, dan kandungan oksigen.

Penelitian berikutnya [7], dengan judul The Application of Internet of Things System for Water Quality Monitoring. Penelitian ini mendesain dan membangun telemetri untuk keasaman $(\mathrm{pH})$ dan konduktivitas. Piranti yang digunakan adalah sensor $\mathrm{pH}$ dan konduktivitas, RTC (Real Time Clock), data logger, dan XBee PRO sebagai media komunikasi nirkabel. Berdasarkan hasil pengujian disimpulkan bahwa pada kondisi LOS XBee PRO mampu mentransmisikan data sejauh $500 \mathrm{~m}$. Sensor keasaman $(\mathrm{pH})$ mampu menjangkau $\mathrm{pH} \quad 1$ sampai dengan 14, serta memiliki akurasi $100 \%$ dengan kertas lakmus sebagai pembanding. Sensor konduktivitas dengan menggunakan elektroda 2 kutub memiliki akurasi sebesar 94,483\%. Penelitian ini menggunakan satu node sehingga terbatas untuk pengaplikasiannya untuk jumlah sampel lebih dari satu.

Penelitian berjudul Sistem Pemantauan Kadar pH, Suhu dan Warna pada Air Sungai Melalui Web Berbasis Wireless Sensor Network [8]. Penelitian tersebut mengembangkan purwarupa sistem pemantauan kadar $\mathrm{pH}$, suhu dan warna yang dapat dipantau melalui web. Hasil pengujian didapatkan bahwa pembacaan sensor dapat dibaca oleh seluruh node dan diterima oleh sink serta dapat ditampilkan melalui laman web yang telah dibangun.

Penelitian oleh Ghulam Imaduddin dan Andi Saprizal (2017) [9] yaitu otomatisasi monitoring dan pengaturan keasaman larutan dan suhu air kolam ikan pada pembenihan ikan lele. Penelitian ini membuat otomatisasi monitoring kadar $\mathrm{pH}$ dan suhu menggunakan Electrode Eutech Instrument pH Meter Kit sebagai sensor $\mathrm{pH}$, LM35 sebagai sensor suhu serta pengontrolan ketinggan air menggunakan sensor ultrasound HCSR-04. Output pengukuran
pH dan suhu air ditampilkan pada layar LCD dan pada monitor dalam bentuk grafik sehingga memudahkan pembudidaya ikan lele memonitoring kondisi air kolam ikan.

Selanjutnya penelitian yang dilakukan [7] berjudul sistem monitoring kualitas air pada kolam ikan berbasis wireless sensor network menggunakan komunikasi zigbee. Penelitian tersebut merancang alat yang dapat mengontrol kualitas air kolam berbasis wireless sensor network. Berdasarkan hasil pengujian dapat disimpulkan bahwa sensor keasaman $(\mathrm{pH})$ mampu menjangkau $\mathrm{pH}$ nilai 1 sampai dengan 14 , serta memiliki akurasi diatas $90 \%$ dengan kertas $\mathrm{pH}$ meter sebagai pembanding. Sensor suhu juga memiliki akurasi diatas $90 \%$.

\section{Metode Penelitian}

\section{A. Metode Pengumpulan Data.}

\section{1) Studi Literatur}

Studi literature dilakukan dengan mempelajari kajian-kajian yang pernah dilakukan oleh peneliti sebelumnya dengan bersumber dari buku, jurnal-jurnal, prosiding yang relevan. Juga dipelajari tentang perangkatperangkat utama terkait perancangan penelitian ini.

\section{2) Observasi}

Metode adalah dengan melakukan pengamatan langsung kelapangan untuk mendapatkan permasalahan yang sebenarnya dalam pembudidayaan ikan.

\section{3) Perancangan perangkat}

Metode ini diawali dengan merancang konsep dari gambaran permasalahan yang telah diperolah dari observasi lapangan dan kemudian dilanjutkan dengan membuat perangkat sesuai dengan tujuan yang ingin dicapai.

\section{B. Perancangan Sistem}

Perangkat yang dirancang pada penelitian ini dibagi atas empat bagian utama, yaitu bagian sensor, bagian pemproses, bagian pengirim data, dan bagian output. Perangkat ini juga terdapat 3 jenis kolam yang berbeda.

Bagian input terdiri dari sensor salinitas (kadar garam), sensor kesadahan (kadar zat 
kapur) dan sensor suhu. Semua sensor tersebut ditempatkan/ dimasukkan pada kolam utama tempat pembudidayaan.

Bagian pemproses terdiri dari Arduino Uno yang akan mengatur fungsi kerja dari sistem sensor dan memberi perintah pada perangkat output. Bagian Ethernet Shield adalah perangkat yang berfungsi mengirimkan data dan terhubung dengan jaringan komputer. Sedangkan bagian output terdiri dari PC/Laptop dan LCD sebagai perangkat monitoring dan kontrol yang akan menampilkan hasil pengolahan data dari pembacaan sensor-sensor.

Pada bagian output ini juga terdapat 3 pompa air serta pemanas air yang akan beroperasi sesuai keadaan temperatur air yang telah ditentukan. Setiap pompa ditempatkan di 3 jenis kolam, yaitu kolam utama, kolam pendingin dan kolam pemanas. Khusus instrumen pemanas air ditempatkan pada kolam pemanas. Pemanas air yang digunakan adalah pemanas air minum dengan elemen sederhana yang umum dijual dipasaran.

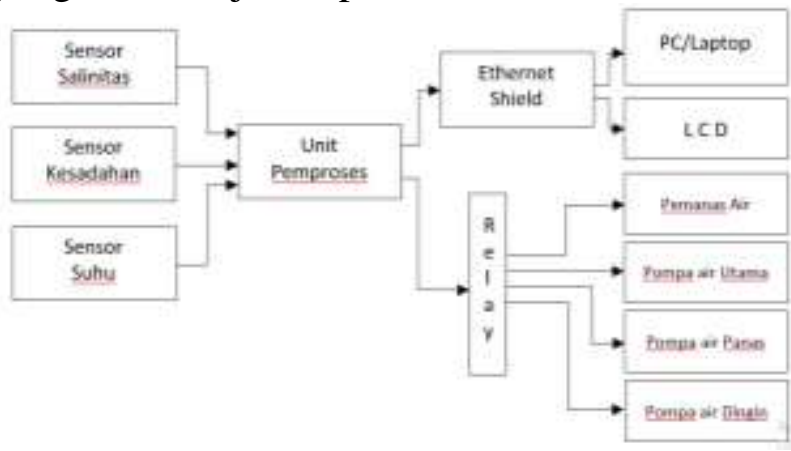

Gambar 1. Blok diagram sistem

Sensor salinitas penelitian ini menggunakan sensor konduktivitas yaitu terdiri dari dua elektroda yang dimasukkan pada kolam /air laut dan kemudian dialiri arus listrik. Daya hantar listik larutan ini yang kemudian akan menjadi masukan pada rangkaian ADC pada Arduino.

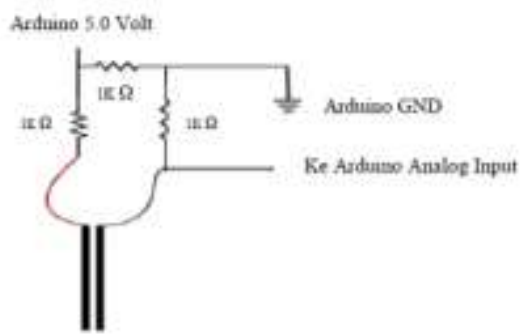

Gambar 2. Perancangan sensor salinitas
Sensor suhu penelitian ini menggunakan sensor type LM35 dengan tegangan keluaran analog. Range suhu yang dapat dideteksi sensor ini adalah $-55{ }^{\circ} \mathrm{C}$ sampai $150{ }^{\circ} \mathrm{C}$. Tegangan output sensor ini bervariasi dari -1 volt sampai 5 volt sesuai kondisi suhu disekitar sensor. Tegangan output sensor naik sebesar $10 \mathrm{mV} /{ }^{\circ} \mathrm{C}$.

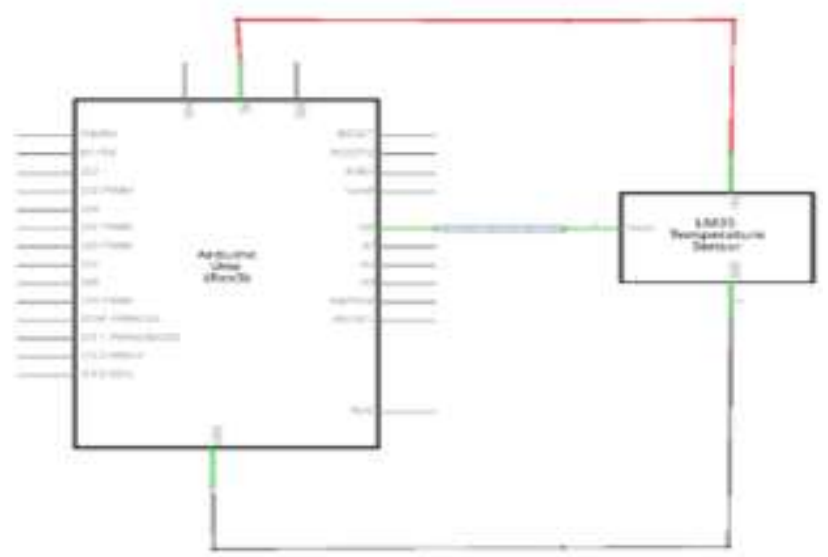

Gambar 3. Perancangan sensor suhu

Sensor kesadahan pada penelitian ini menggunakan metal keping yang terbuat dari bahan perak. Metal tersebut dialiri tegangan 5 volt DC sebagai pendeteksi perubahan resistansi. Tegangan output dari kepingan metal ini diteruskan menjadi masukan bagi ADC Arduino. Sensor ini mengukur kandungan kadar zat kapur (CaCO3) dalam satuan ppm.

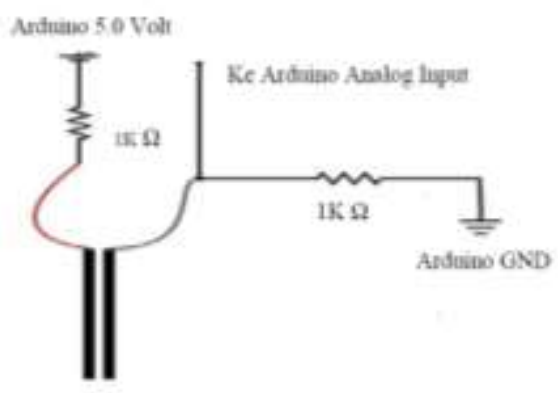

Gambar 4. Perancangan sensor kesadahan

Pada perancangan penelitian ini, diperlukan pula perangkat lunak guna mendukung perancangan sistem keseluruhan. Berikut ini perangkat lunak, perancangan dan fungsinya:

\section{1) Arduino Uno IDE}

Arduino IDE (Integrated Development Environment) adalah perangkat lunak yang berfungsi untuk mengkonfigurasi board mikrokontroler Arduino Uno yang berisi editor 
teks untuk menulis kode, area pesan, konsol teks, toolbar dengan tombol untuk fungsi-fungsi umum dan serangkaian menu. Sistem operasional yang kompetibel digunakan yaitu Windows, Mac OS X, Linux. Pada perancangan penelitian ini sistem operasional yang digunakan adalah Windows.

\section{2) Perancangan Halaman WEB}

Monitoring kualitas air kolam ikan budidaya pada penelitian ini berbasis website. Web adalah tampilan pada browser dengan alamat domain khusus. Web dapat dibangun dengan menggunakan bahasa PHP dan HTML dengan tampilan menggunakan bahasa CSS. Web tersebut disimpan pada satu komputer sebagai server. Selain menyimpan program web, Server juga menyimpan database untuk dapat diakses oleh admin atau client dari browser. Website tersebut dibangun menggunakan program notepad ++ . Berikut ini adalah tampilan dari perangkat lunak notepad++ .

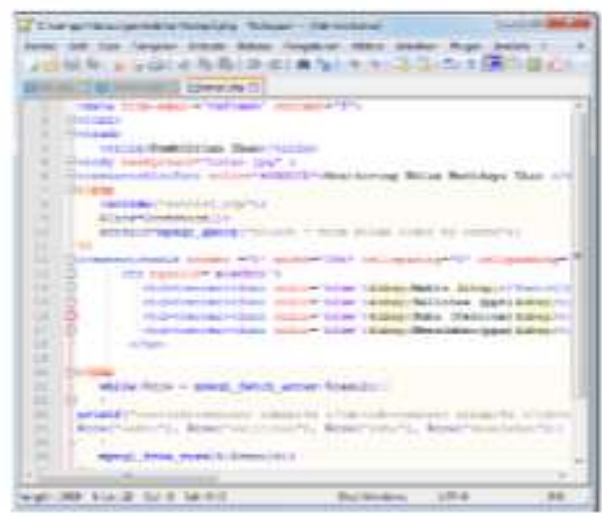

Gambar 5. Tampilan perangkat lunak notepad++

\section{3) Perancangan Database}

Fungsi dari database adalah sebagai media penyimpan yang dapat diakses oleh web. Database dibangun dengan menggunakan phpmyadmin yang dapat dibuka dengan mengakses halaman http://localhost/phpmyadmin dari browser dengan terlebih dahulu menginstall aplikasi XAMPP (X, Apache, Mysql, PHP, Perl). Database yang dirancang ini menyimpan tabel hasil pengukuran kualitas air (Waktu, Salinitas, Suhu, Kesadahan). Berikut ini adalah tampilan dari XAMPP dan phpMyAdmin.

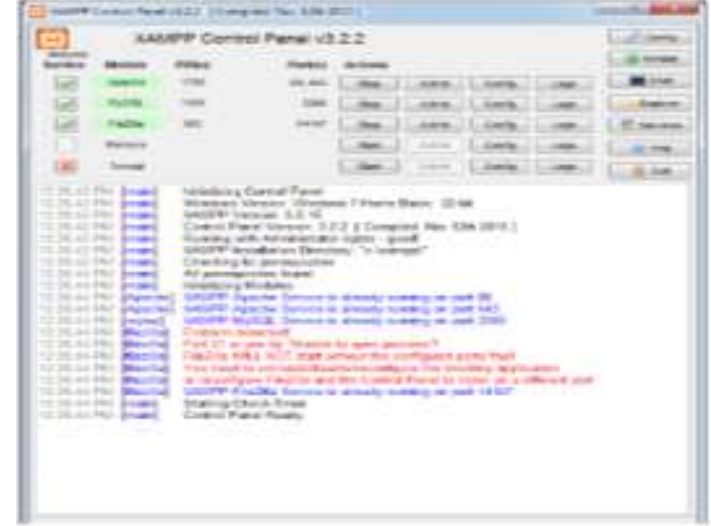

Gambar 6. Tampilan perangkat lunak XAMPP

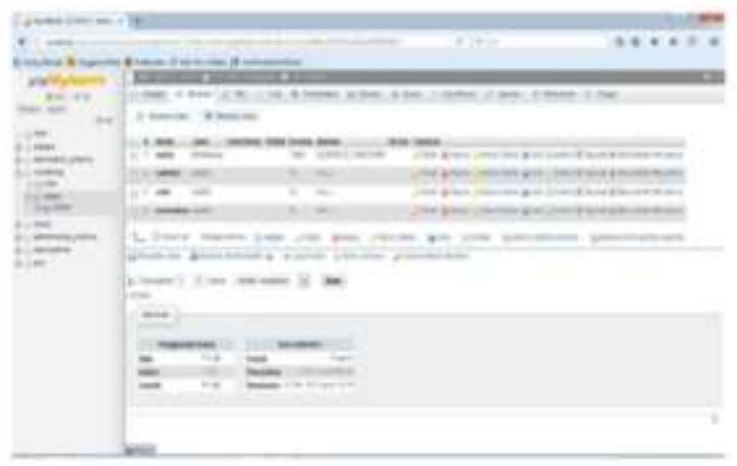

Gambar 7. Tampilan Database

\section{Cara Kerja Perangkat}

Perangkat input pada penelitian ini terdiri dari tiga sensor yaitu sensor salinitas, sensor suhu, dan sensor kesadahan yang ditempatkan didalam air. Setiap sensor akan mendeteksi dan mengukur keadan kualitas air kolam sesuai fungsinya masing-masing. Informasi dari sensor tersebut adalah data hasil pengukuran berupa data analog. Data analog tersebut selanjutnya diteruskan ke bagian pemproses data yaitu Arduino Uno, pada proses ini data diubah menjadi bentuk data digital. Data digital ini kemudian ditampilkan pada bagian output yang berfungsi sebagai monitoring dan kontrol yaitu LCD dan PC/Laptop. LCD dihubungkan dari Arduino dengan menggunakan kabel jumper, dan PC/Laptop dihubungkan menggunakan Ethernet Shield yang ditampilkan pada web melalui aplikasi Mozilla, Chrome atau sejenis lainnya.

Selain berfungsi sebagai monitoring yang menampilkan suhu terukur pada kolam budidaya, web pada penelitian ini juga difungsikan untuk menentukan nilai suhu yang harus diterapkan pada kolam budidaya tersebut. 
Sehingga sistem akan bekerja berdasarkan nilai suhu/temperature yang ditetapkan pada web tersebut.

Bila suhu air pada kolam budidaya melebihi dari nilai suhu yang ditetapkan pada web, maka sistem akan bekerja untuk mendinginkan kolam tersebut agar temperatur kolam kembali normal sesuai dengan suhu yang ditentukan. Sistem pendingin dalam rancangan ini menggunakan air biasa yang disupply dari luar kolam utama budidaya. Air dingin tersebut dipompa kedalam kolam budidaya dengan pompa air dingin, dan secara bersama sebagian air pada kolam utama dipompa keluar dengan pompa air utama.

Bila suhu air pada kolam kurang dari suhu yang ditetapkan pada web, maka sistem akan memerintahkan bagian pemanas air bekerja untuk memanaskan air pada kolam khusus air panas. Sistem pemanas pada rancangan penelitian ini menggunakan element pemanas. Air panas selanjutnya dipompa menuju kolam utama budidaya agar suhu kolam tersebut mencapai keadaan normal sesuai yang telah ditetapkan web.

\section{PengujIan Dan Analisis}

\section{A. Pengujian Perangkat}

1) Pengujian Sensor Salinitas

Pengujian sensor salinitas dilakukan pada dua kondisi yaitu pada air laut dan air tawar yang dilakukan untuk mengetahui tingkat kadar garam terlarut yang terdapat pada kedua jenis air tersebut. Pengujian sensor dilakukan sebanyak sepuluh kali dengan jeda waktu selama 10 menit dan menggunakan alat ukur pembanding pabrikan (refracto).

Berikut hasil perhitungan:

$$
\begin{aligned}
\text { Tegangan } & =\text { Data ADC } x \text { Ketelitian } \\
\text { terukur } & =664 \times 0,00488281 \\
& =3,24 \text { Volt } \\
\text { Ketelitian } & =\text { Avcc/jumlah bit } \\
& =5 / 1024 \\
& =0,00488281 \text { Volt } \\
& =4,88281 \mathrm{mv}
\end{aligned}
$$

Bila data ADC yang terbaca 664, maka konversi kadar kesadahan air dalam satuan per 100 menjadi (ppt) adalah:

$$
\begin{aligned}
\text { Ppt } & =\text { Data ADC x ketelitian x } 9 \\
& =664 \times 0,00488281 \times 9 \\
& =29 \mathrm{ppt}
\end{aligned}
$$

\section{Perhitungan error:}

error: $\frac{\text { Rata-ratanilaiperangkat yangterukut }}{\text { Rata-ratanilai alat pembanding yang terukur }} \times 100$

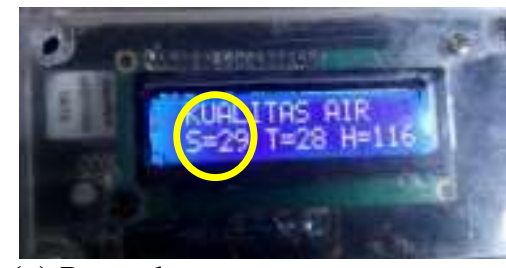

(a) Perangkat rancangan

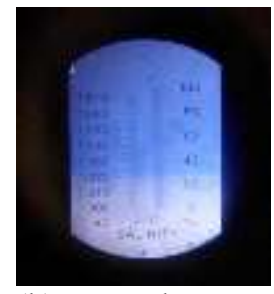

(b) Perangkat pembanding
Gambar 8. Pengujian salinitas pada air laut

Tabel 1. Hasil pengujian salinitas pada air laut

\begin{tabular}{ccccc}
\hline Ne & $\begin{array}{c}\text { Data ADC yang } \\
\text { terbaca }\end{array}$ & $\begin{array}{c}\text { Tegangan } \\
\text { (Velf) }\end{array}$ & $\begin{array}{c}\text { Salinitas } \\
\text { (ppm) }\end{array}$ & $\begin{array}{c}\text { Refructo } \\
\text { (ppm) }\end{array}$ \\
\hline 1 & 664 & 3,24 & 29 & 31 \\
2 & 670 & 3,27 & 29 & 30 \\
3 & 671 & 3,28 & 29 & 29 \\
4 & 672 & 3,28 & 29 & 29 \\
5 & 673 & 3,29 & 29 & 30 \\
6 & 674 & 3,29 & 29 & 29 \\
7 & 674 & 3,29 & 29 & 30 \\
8 & 675 & 3,30 & 29 & 29 \\
9 & 675 & 3,30 & 29 & 30 \\
10 & 675 & 3,30 & 29 & 30 \\
\hline
\end{tabular}

Dari tabel pengujian diatas, tingkat error sensor salinitas perangkat rancangan ini pada air laut dibanding dengan perangkat ukur pembanding (refrakto) adalah $2,4 \%$.

Pengujian salinitas dengan metode yang sama pada air tawar diperoleh hasil:

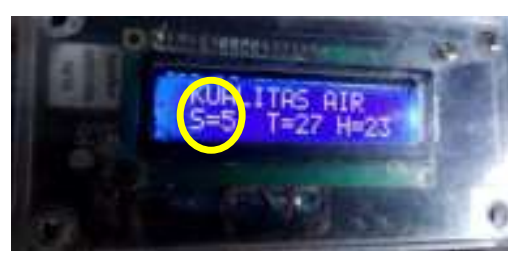

(a) Perangkat rancangan

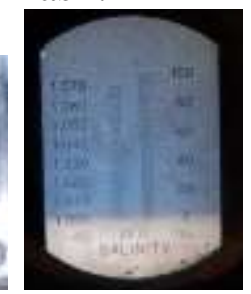

(b) Perangkat pembanding
Gambar 9. Pengujian salinitas pada air tawar 
Tabel 2. Hasil pengujian salinitas pada air tawar

\begin{tabular}{ccccc}
\hline $\begin{array}{c}\text { D } \\
0\end{array}$ & $\begin{array}{c}\text { Data ADC yang } \\
\text { terbaca }\end{array}$ & $\begin{array}{c}\text { Teganga } \\
\text { a (Voli) }\end{array}$ & $\begin{array}{c}\text { Salinitas } \\
\text { (ppt) }\end{array}$ & $\begin{array}{c}\text { Refracto } \\
\text { (ppen) }\end{array}$ \\
\hline 1 & 127 & 0,62 & 5 & 0 \\
2 & 127 & 0,62 & 5 & 0 \\
3 & 128 & 0,63 & 5 & 0 \\
4 & 129 & 0,63 & 5 & 0 \\
5 & 130 & 0,63 & 5 & 0 \\
5 & 131 & 0.64 & 5 & 0 \\
6 & 131 & 0.64 & 5 & 0 \\
7 & 131 & 0.64 & 5 & 0 \\
8 & 132 & 0.64 & 5 & 0 \\
9 & 132 & 0.64 & 5 & 0 \\
10 & 132 & & & \\
\hline
\end{tabular}

Pengujian salinitas perangkat pada air tawar dengan alat ukur pembanding refracto berbeda, ini dikarenakan sensor salinitas melakukan pengukuran berdasarkan konduktivitas pada air tawar, namun hal tersebut bisa dikatakan berjalan normal.

2) Pengujian Sensor Suhu

Pengujian sensor suhu dilakukan pada dua lokasi berbeda yaitu pada air laut dan air tawar. Pengujian dilakukan dengan mencelupkan sensor suhu kedalam dua jenis air tersebut dan diukur perubahan tegangan yang terjadi pada sensor LM35.

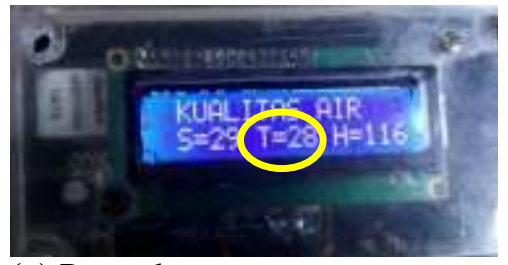

(a) Perangkat rancangan

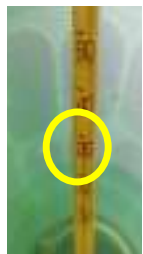

(b) Thermometer pembanding
Gambar 10. Pengujian suhu pada air laut

Pengujian suhu menggunakan LM35 dilakukan sebanyak sepuluh kali dengan jeda waktu 10 menit, selanjutnya hasil pengukuran tersebut dibandingkan dengan thermometer yang sesuai standar pengukuran suhu cairan.

Berikut hasil pengujian sensor suhu:

Tabel 3. Hasil pengujian suhu pada air laut

\begin{tabular}{ccccc}
\hline No & Data ADC yasg terbaca & $\begin{array}{c}\text { Tegangan } \\
\text { (Veln) }\end{array}$ & $\begin{array}{c}\text { Suhu L.M35 } \\
\text { (C) }\end{array}$ & $\begin{array}{c}\text { Thermamerer } \\
\text { ('C) }\end{array}$ \\
\hline 1 & 64 & 0,31 & 28 & 30 \\
2 & 64 & 0,31 & 28 & 30 \\
3 & 64 & 0,31 & 28 & 29 \\
4 & 64 & 0,31 & 28 & 28 \\
5 & 64 & 0,31 & 28 & 28 \\
6 & 64 & 0,31 & 28 & 29 \\
7 & 63 & 0,31 & 27 & 29 \\
8 & 64 & 0,31 & 28 & 28 \\
9 & 63 & 0,31 & 27 & 27 \\
10 & 65 & 0,31 & 27 & 27 \\
\hline
\end{tabular}

Pengujian suhu pada tabel diatas rata - rata hasil pengukuran sensor adalah $27,7{ }^{\circ} \mathrm{C}$ dan pada thermometer pembandingnya rata - rata suhu yang terukur adalah $28,5{ }^{\circ} \mathrm{C}$, tingkat error perangkat rancangan ini adalah 2,9\%.

Pengujian suhu dengan metode yang sama pada air tawar diperoleh hasil sebagai berikut:

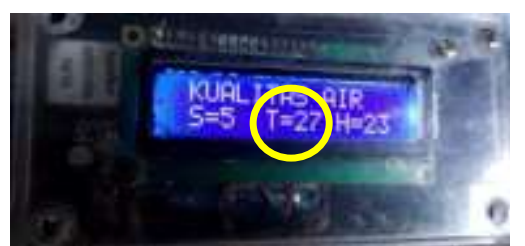

(a) Perangkat rancangan

Gambar 11. Pengujian suhu pada air tawar

Tabel 4. Hasil pengujian suhu pada air tawar

\begin{tabular}{|c|c|c|c|c|}
\hline Ne & Data ADC yang terbaca & $\begin{array}{c}\text { Tegangan } \\
\text { (Nolt) }\end{array}$ & $\begin{array}{c}\text { Suha LM35 } \\
\text { (FC) }\end{array}$ & $\begin{array}{c}\text { Therwouncter } \\
\text { ("C) }\end{array}$ \\
\hline I & 64 & $0.3 !$ & 28 & 29 \\
\hline 2 & 63 & 0.31 & 27 & 28 \\
\hline 3 & 63 & 0.31 & 27 & 28 \\
\hline 4 & 63 & 0.31 & 27. & 27 \\
\hline 5 & 64 & 0.31 & 28 & 29 \\
\hline 6 & 63 & 0,31 & 27 & 28 \\
\hline 7 & 63 & 0.31 & 27 & 29 \\
\hline 8 & 63 & 0.31 & 27 & 29 \\
\hline 9 & 63 & 0,31 & 27 & 28 \\
\hline 10 & 63 & 0,31 & 27 & 28 \\
\hline
\end{tabular}

Pengujian suhu pada tabel diatas rata-rata adalah 27,2 ${ }^{\circ} \mathrm{C}$ dan pada thermometer pembandingnya rata-rata suhu yang terukur adalah $28,3{ }^{\circ} \mathrm{C}$, dengan tingkat error $3,9 \%$.

3) Pengujian Sensor kesadahan

Pengujian sensor kesadahan dilakukan pada air tawar karena kesadahan hanya berlaku pada air tawar. Hasil pengujian ini hanya dilihat dari perbedaan ukur antara air yang telah di panaskan dengan air yang belum dipanaskan.

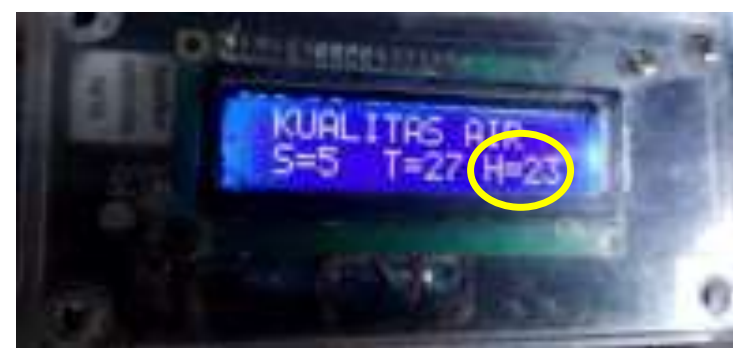

Gambar 12. Pengujian kesadahan pada air tawar yang belum dipanaskan 
Pramana, Perancangan Sistem Kontrol dan Monitoring Kualitas Air dan Suhu Air Pada Kolam Budidaya Ikan

Berikut hasil pengujian sensor kesadahan pada air tawar yang belum di panaskan:

Tabel 5. Hasil pengujian kesadahan pada air tawar yang belum dipanaskan

\begin{tabular}{cccc}
\hline No & Data ADC yang terbaca & $\begin{array}{c}\text { Tegangan } \\
\text { (Volt) }\end{array}$ & $\begin{array}{c}\text { Kesadahan } \\
(\mathrm{ppm})\end{array}$ \\
\hline 1 & 130 & 0,63 & 22 \\
2 & 130 & 0.63 & 22 \\
3 & 131 & 0,63 & 23 \\
4 & 132 & 0,64 & 23 \\
5 & 132 & 0,64 & 23 \\
6 & 133 & 0,64 & 23 \\
7 & 133 & 0,64 & 23 \\
8 & 133 & 0,64 & 23 \\
9 & 133 & 0,64 & 23 \\
10 & 134 & 0,65 & 23 \\
\hline
\end{tabular}

Nilai rata-rata dari pengukuran kesadahan pada pengujian tersebut adalah $22,8 \mathrm{ppm}$, ini dikarenakan air tersebut terkandungan senyawa kalsium bikarbonat dan magnesium bikarbonat.

Pengujian sensor kesadahan dengan metode yang sama pada air yang telah dipanaskan diperoleh hasil sebagai berikut:

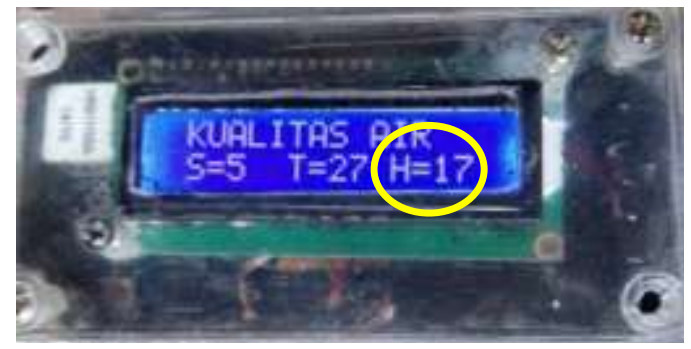

Gambar 13. Pengujian sensor kesadahan pada air tawar yang telah dipanaskan

Hasil pengujian sensor kesadahan tersebut dapat dilihat pada tabel berikut.

Tabel 6. Hasil pengujian sensor kesadahan pada air tawar yang belum dipanaskan

\begin{tabular}{cccc}
\hline No Data ADC yang terbaca & $\begin{array}{c}\text { Trgangan } \\
\text { (Volt) }\end{array}$ & $\begin{array}{c}\text { Kevadahan } \\
\text { (ppm) }\end{array}$ \\
\hline 1 & 97 & 0,47 & 17 \\
2 & 100 & 0,48 & 17 \\
3 & 100 & 0,48 & 17 \\
4 & 101 & 0,49 & 17 \\
5 & 102 & 0,49 & 17 \\
6 & 103 & 0,50 & 18 \\
7 & 104 & 0.50 & 18 \\
8 & 104 & 0.50 & 18 \\
9 & 105 & 0.51 & 18 \\
10 & 105 & 0.51 & 18 \\
\hline
\end{tabular}

Niilai rata-rata dari pengukuran kesadahan pada air yang telah dipanaskan perangkat ini adalah 17,5 ppm. Bila dibandingkan dengan pengujian terhadap air yang belum dipanaskan, terdapat penurunan nilai kesadahan air setelah dipanaskan. Ini terjadi karena setelah pemanasan senyawa akan terbebas dari ion kalsium dan magnesium yang dan menyebabkan senyawa akan mengendap.

\section{4) Pengujian pompa air}

Pompa pada perangkat rancangan ini terdiri dari 3 buah pompa yang terdapat pada kolam utama, kolam pendingin dan kolam pemanas. Pompa pada kolam utama berfungsi sebagai pembuang air pada kolam utama, pompa ini akan mempercepat kondisi pada air kolam yang dalam keadaan suhu dingin/panas berlebih kembali kepada suhu normal. Pompa pada kolam pendingin berfungsi untuk memompa air dingin dari kolam pendingin menuju kolam utama. Pompa kolam air panas berfungsi untuk memompa air panas dari kolam pemanasan menuju kolam utama.

Setiap pompa air dikendalikan dengan relay. Channel 1 pada relay digunakan untuk pompa kolam utama, channel 2 pada relay digunakan untuk pompa air dingin dan channel 3 pada relay digunakan untuk pompa air panas. Beroperasinya setiap pompa bergantung pada aktif atau tidak aktifnya relay pada setiap channel 1, channel 2 atau channel 3 tersebut.

\section{5) Pengujian pemanas air}

Pemanas air pada perangkat rancangan ini berfungsi untuk memanaskan air pada kolam pemanas. Air pada kolam pemanas tersebut akan digunakan untuk menaikan suhu pada kolam utama bila suhu pada kolam utama tersebut berada dibawah suhu yang ditentukan. Pemanas air menggunakan relay channel 4 yang terhubung sebelumnya dengan bagian pemproses. Ketika channel 4 relay aktif, maka pemanas air pun aktif dan ketika channel 4 relay tidak aktif, maka pemanas air pun ikut tidak aktif. Pemanas air beroperasi bergantung pada pembacaan sensor suhu pada kolam utama budidaya tersebut.

Kapasitas pemanas air pada perangkat rancangan ini dapat memanaskan air sebanyak 4 liter selama 5 menit dari suhu $29,5{ }^{\circ} \mathrm{C}$ hingga suhu $39,5^{\circ} \mathrm{C}$. 
Tabel 7. Hasil pengujian Pemanas air

\begin{tabular}{cccc}
\hline \multicolumn{2}{c}{$\begin{array}{c}\text { Perubahan kenaikan } \\
\text { Suhu }\end{array}$} & \multicolumn{2}{c}{$\begin{array}{c}\text { Perubahan penurunan } \\
\text { Suhu }\end{array}$} \\
\hline Suhu $\left({ }^{\mathbf{0}} \mathbf{C}\right)$ & $\begin{array}{c}\text { Waktu } \\
\text { (detik) }\end{array}$ & Suhu $\left({ }^{\mathbf{o}} \mathbf{C}\right)$ & $\begin{array}{c}\text { Waktu } \\
\text { (detik) }\end{array}$ \\
\hline 24 & 0 & 31 & 0 \\
24,1 & 264 & 30,9 & 18 \\
24,2 & 528 & 30,8 & 36 \\
24,3 & 792 & 30,7 & 54 \\
24,4 & 1056 & 30,6 & 72 \\
24,5 & 1320 & 30,5 & 90 \\
24,6 & 1584 & 30,4 & 108 \\
24,7 & 1848 & 30,3 & 126 \\
24,8 & 2112 & 30,2 & 144 \\
24,9 & 2376 & 30,1 & 162 \\
25 & 2640 & 30 & 180 \\
\hline
\end{tabular}

B. Analisis

Pengujian sensor salinitas air pada perangkat ini memiliki tingkat ketelitian mencapai 97,6 \% dengan error $2,4 \%$.

Pengujian suhu air dilakukan pada dua lokasi yaitu pada air laut dan air tawar. Pada air laut tingkat ketelitian sensor suhu mencapai 97,1\% dengan error $2,9 \%$ sedangkan pada air tawar 96,1\% dengan tingkat error 3,9\%.

Pengujian sensor kesadahan dilakukan pada air biasa (normal) dan air panas. Hasilnya, pada air normal nilai pembacaan sensor sebesar 22 ppm, dan pada air panas nilai pembacaan sensor sebesar $17 \mathrm{ppm}$.

Suhu yang ingin diatur pada kolam utama dapat diinputkan menggunakan aplikasi komputer/laptop yang dirancang. Suhu dapat diinput baik secara manual maupun dari pilihan yang tersedia pada monitor aplikasi.

Perangkat pemproses membutuhkan waktu untuk meng-update perubahan suhu setiap 2 detik, yaitu 1 detik untuk mengukur suhu serta untuk meng-upload hasil pengukuran ke database dan 1 detik sebagai delay sebelum pengukuran suhu berikutnya. Bila sensor suhu kolam utama mengukur kelebihan suhu dari batas yang ditetapkan, bagian pemproses memerintahkan pompa air pada kolam utama dan kolam pendingin mulai beroperasi. Air pada kolam utama akan dikeluarkan dan pada saat yang sama air pada kolam pendingin dimasukkan ke kolam utama sampai pembacaan suhu pada kolam utama kembali normal sesuai suhu yang ditentukan. Proses ini membutuhkan waktu 6 detik.

Bila sensor suhu kolam utama mengukur suhu air kurang dari batas suhu yang ditetapkan, bagian pemproses memerintahkan pengaktifan bagian pemanas pada kolam pemanas, pompa air pada kolam utama dan kolam pemanas mulai beroperasi. Proses ini membutuhkan waktu 66 detik. 60 detik pertama adalah untuk memanaskan air pada kolam pemanas, selanjutnya pompa air utama beroperasi mengeluarkan air pada kolam utama dan secara bersamaan air pada kolam pemanas dipompa dimasukkan ke kolam utama sampai pembacaan suhu pada kolam utama naik dan kembali normal sesuai suhu yang ditentukan.

Dari pengujian diperoleh hasil bahwa pada kolam berkapasitas 10 liter, untuk menaikan suhu sebesar $0,1^{\circ} \mathrm{C}$ dibutuhkan 4 kali sirkulasi dengan waktu 264 detik atau 4,4 menit, untuk menaikan suhu sebesar $1^{\circ} \mathrm{C}$ dibutuhkan 40 kali sirkulasi dengan waktu 2640 detik atau 44 menit. Elemen pemanas yang digunakan pada pengujian tersebut berjumlah 1 dan berukuran kecil. Untuk mempercepat kenaikan suhu bisa digunakan elemen pemanas berukuran besar atau memperbanyak elemen pada kolam pemanas.

Untuk menurunkan suhu $0,1^{\circ} \mathrm{C}$ pada kolam berkapasitas 10 liter, diperlu 3 kali sirkulasi dengan waktu 18 detik dan untuk menurunkan suhu $1{ }^{\circ} \mathrm{C}$ diperlukan 30 kali sirkulasi dengan waktu 180 detik atau 3 menit. Waktu penurunan suhu bisa dipercepat dengan mempercepat debit air pompa pada kolam pendingin.

Dalam menaikkan atau menurunkan suhu pada kolam, perlu memperhatikan karakteristik jenis ikan budidaya tersebut. Ikan jenis tertentu memiliki sensitifitas pada perubahan suhu.

Hasil ukur sensor dikirimkan ke web local host melalui Ethernet Shield. Pembacaan hasil ukur dan pengontrolan kolam dapat dimonitoring dan dikontrol secara otomatis menggunakan komputer/laptop.

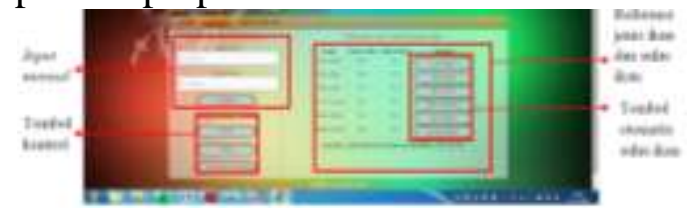

Gambar 14. Tampilan aplikasi kontrol melalui web 


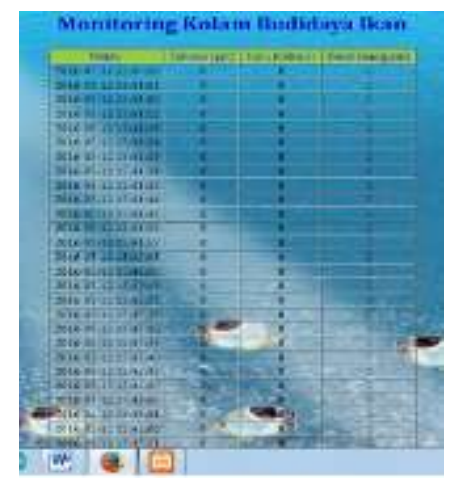

Gambar 15. Tampilan aplikasi monitoring melalui web

\section{KESIMPULAN}

Penelitian yang telah dilakukan ini dapat disimpulkan sebagai berikut:

1. Perangkat sistem kontrol serta monitoring kualitas air dan suhu air kolam budidaya ikan ini dapat dioperasikan dengan mudah dan efektif. Persentase error dari pembacaan sensor adalah berkisar $2,4 \%-3,9 \%$.

2. Aplikasi yang dijalankan melalui web sangat efektif untuk meng-inputkan nilai suhu yang ingin ditetapkan pada kolam melalaui komputer/laptop, dan pembacaan nilai-nilai sensor yang terukur dapat dimonitoring.

3. Perangkat mampu mengkontrol perubahan suhu pada kolam budidaya secara otomatis, penurunan suhu sebesar $0,1^{\circ} \mathrm{C}$ pada kolam berkapasitas 10 liter membutuhkan waktu 18 detik, dan untuk menurunkan suhu sebesar $1{ }^{\circ} \mathrm{C}$ membutuhkan waktu 180 detik (3 menit).

4. Untuk menaikan suhu sebesar $0,1^{\circ} \mathrm{C}$ dibutuhkan waktu 264 detik atau 4,4 menit, dan untuk menaikan suhu sebesar $1{ }^{\circ} \mathrm{C}$ dibutuhkan waktu 2640 detik atau 44 menit.

5. Waktu untuk menaikan suhu pada air kolam lebih lama dari pada menurunkkan suhu. Waktu tersebut dapat dipersingkat dengan menggantikan elemen pemanas yang lebih besar atau menambahkan elemen pemanas pada kolam pemanas.

\section{UCAPAN TERIMA KASIH}

Puji syukur peneliti kepada Allah SWT atas Rahmat dan Karunia yang diberikan oleh-NYA. Juga terimakasih kepada redaktur, reviewer dan editor Jurnal Sustainable atas kerja kerasnya membantu penulis.

\section{REFERENSI}

[1] N. Ridho., dan R. Pramana, "Konsep Sistem Penyelamatan di Laut dengan Pemanfaatan VTS dan Mikrokontroller", Jurnal Sustainable, Volume 4 No.1, ISSN 20875347, Mei 2013.

[2] D.S. Maradong, "Potensi Besar Perikanan Tangkap Indonesia”, Deputi Bidang Kemaritiman, Sekretariat Kabinet, http://setkab.go.id, 2016.

[3] Suripin, "Pelestarian sumber daya tanah dan air", Penerbit Andi, Yogyakarta, 2002.

[4] A.P. Simanjuntak., R.Pramana., dan D. Nusyirwan, "Pengontrol Suhu Air Pada Kolam Pendederan Dan Pembenihan Ikan Nila Berbasis Arduino", Jurnal Sustainable, Volume 4 No.1, Mei 2013, ISSN 2087-5347

[5] S. Mahfudz, dan P.M. Rahardjo, "Pengukur Suhu dan $\mathrm{pH}$ Tambak Air Terintegrasi dengan Data Logger", Jurnal EECCIS, Vol. II: hal 22-25, 2008.

[6] S. Sridharan, "Water Quality Monitoring System Using Wireless Sensor Network", International Journal of Advanced Research in Electronics and Communication Engineering (IJARECE), Volume 3, Issue 4, ISSN: 2278 - 909X, 2014.

[7] T. Yuwono, L. Hakim, I. Ardi, dan T. Umar, "The Application of Internet of Things System for Water Quality Monitoring", Internetworking Indonesia Journal, Vol. 8, No.1, 2016.

[8] A. Sabiq dan P. N. Budisejati, "Sistem Pemantauan Kadar pH, Suhu dan Warna pada Air Sungai Melalui Web Berbasis Wireless Sensor Network," Jurnal Teknologi dan Sistem Komputer, vol. 5, no. 3, pp. 94100, Jul. 2017.

[9] G. Imaduddin dan A. Saprizal, "otomatisasi monitoring dan pengaturan keasaman larutan dan suhu air kolam ikan pada pembenihan ikan lele" Jurnal Sistem Informasi, Teknologi 
Informatika dan Komputer Volume 7, Nomor 2, ISSN 2089-0265, 2017.

[10] E. Lintang, Firdaus, dan I. Nurcahyani, "Sistem Monitoring Kualitas Air pada Kolam Ikan Berbasis Wireless Sensor Network menggunakan Komunikasi Zigbee", Prosiding SNATIF, ISBN: 978602-1180-50-1, 2017. 